"From Dector William P. Dewees, Adjunet Professor of Midwifcry in the University of I'ennsylvania, etc.

"I have much pleasure in saying I have witnessed the most decided and happy effects in several instances of inveterate disease from Mr. Swain's PANACEA, where other remedies had failed-one that of Mrs. Brown.

$$
\text { "'Wm. P. Dewees, M.D." " }
$$

It goes without saying that these men were in the very forefront of the medical profession in America three-quarters of a century ago, and this fact evoked the following closing paragraph from the editor of the Medico-Chirurgical Review:

"Eheu jam satis! We are mortified and grieved, beyond measure, to find professional propriety (to give it no other name) at so low an ebb among our brethren in America! This admonition from Europe will surely rouse the faculty of the United States to some sense of the duty they owe to their brethren throughout the world."

Charles B. Johvson, M.D., Champaign, Ill.

[Comment: Times change and we change with them! In 1836 British physicians were astounded at the spectacle of American medical men giving testimonials for nostrums. In 1914 American medical men view with astonishment and dismay the tendency on the part of European physicians, Britisla and Continental, to laud proprietary remedies of the most evidently fraudulent type. Testimonial-giving by physicians in the United States is practically a thing of the past; in Great Britain and on the Continent it is so common as to arouse no comment.-ED.]

Imported Medication and Dr. Stelwagon's Formula

To the Editor:-Apropos of the remarks on "Imported Medieation" in the Therapeutics Department (TIIE JourNal, Dec. 13, 1913, p. 2159), it may prove of interest to your readers to compare the prescription headed "A Formula for Combined Stomachic and Laxative Effects," with a startlingly si *ilar prescription given in "Essentials of Diseases of the Skin," by Henry W. Stelwagon, M.D., Ph.D., clinical professor of dermatology in the Jefferson Medical College (Philadelphia, W. B. Saunders Company, 1900, p. 118). In the paragraph describing the constitutional treatment when indicated in acne the author states that "in dyspensia and constipation, bitter tonics, alkalies, acids, pepsin, saline and vegetable laxatives are variously prescribed. Special mention may be made of the following:



M. Sig. : 3 i t. i. d."

Compare this with the formula which you state was "copierl verbatin from the Paris médical':

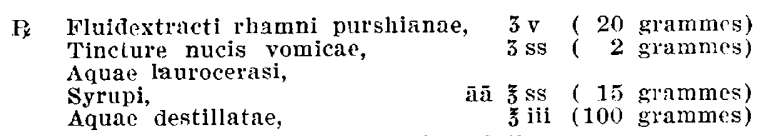

M. Sig.: Thrce or four teaspoonfuls daily.

In other words, one of our leading dermatologists was recommending practically the same formula not less than thirteen years ago. So much for the "newness" of the prescription, as far as its really active ingredients are concerned, namely, the cascara and nux vomica.

Dr. Stelwagon's mixture is not exactly pleasant to take, and the suggestion you make about giving caseara and nux vomica separately is a good one. Still, many patients, in my experience, do not find the mixture much, if at all, more unpleasant to take than the separately administered drugs, preferring one bitter dose to two or three less bitter ones.

Since 1903, first in general medical work and later in eye, ear, nose and throat practice, I have used this formula for the indications outlined by Dr. Stelwagon, with extremely gratifying results, its bitter taste to the contrary notwithstanding. In many patients, particularly women, referred for examination of eyes and nose to find possible cause of headache, 1 have found those organs normal. Many such patients were complaining of constipation, poor but not markedly upset digestion, and more or less anorexia, but other more definite symptoms were not elicited by their physician or myself. Such patients almost invariably were relieved of their head aches by Dr. Stelwagon's formula, or the later and possibly worse-tasting one I used in Panama, in which the compound tincture of cinchona was substituted for the elixir of calisaya. Richard M. Nelson, M.D., Atlanta, Ga.

\section{Blood Transfusion in 1666}

To the Editor:-In reading the celebrated diary of Samuel Pepys I recently eame across the first account, so far as I know, of the transfusion of blood, which I think will be of interest to the readers of The Jocirnal. The following is an extract:

"Nov. the 14th, 1666. Dr. Croone told me that at the meeting at Gresham College to-night (which, it seems, they now have every Wednesday again), there was a pretty experiment of the blood of one dog let out (till he died) into the body of another on one side, while all his own run out on the other side. The first died upon the place, and the other very well, and likely to do well. This did give occasion to many pretty wishes, as of the blood of a Quaker to be let into an Archbishop, and such like; but, as Dr. Croone says, may, if it takes, be of mighty use to man's health, for the amendment of bad blood by borrowing from a better body.

"Nov. 16th. This noon I met with Mr. Hooke, and he tells me the dog which was filled with another dog's blood, at the Collere the other day, is very well,and like to be so as ever, and doubts not its being found of great use to men; and so do Dr. Whistler, who dined with us at the tavern."

Michael Campberc, M.D., Bearden, Tenn.

\section{Queries and Minor Notes}

Anonymous Commonications and queries on postal cards will not be noticed. Fvery letter must contain the writer's name and address, but these will be omitted, on request.

RESPONSIBILITY OF SURGEON IN USE OF ROENTGEN RAY

To the Editor:- There are two legal questions affecting the rights and the interests of the surgeon, concerning which I should like to ask for information.

A. Is there any opinion holding a surgeon responsible for not using the Roentgen riy in fractures and other surgical conditions in which the Roentgen ray might be an aid to diagnosis? Would this bi affected by the inability of the patient to pay the expenses that would have to be incurred?

B. First, is there any opinion holding the surgeon responsible when he tells the ationt in when he tells the patient in advance that the result, under the conditions of the treatment, will not be satisfactory and yet treats the patient with the result foretold? Secondly, if a surgeon treat a patient because of the inability of the patient to pay hospital expenses or surgeon's fees under unfavorable conditions as to if not satistactory? The second question partly covers this.

R. D. 0 .

ANSwER.-The fundamental consideration underlying these questions is, What is the measure of a physician's duty and liability in diagnosing and treating a supposed fracture or a supposed surgical condition of any nature?

In the treatment of any particular case a physician must use such reasonable skill and diligence in applying or administering any medicine or means used as would be exercised by the average physician of the same community under similar circumstances (Spain $v$. Bureh (Mo.), 154 S.W. 172; McGrau, $v$. Kerr (Colo.), 128 Pac. 870; McBride v. Hucliins (N.H.), 81 Atl. 528; Sauyer v. Berthold (Minn.), 134 N.W. 120; Robinson v. Crothucell (Ala.), 57 So. 23; Mosslander $v$. Armstrong (Nebr.), 134 N.W. 967; Hinkle v. Smith (Ga.), 77 S.C. 650; Osborn v. Carey (Idaho), 132 N.W. 967; Booth v. Andrews (Neb.), 137 N.W. 884).

A.--Is a physician bound to use the Roentgen ray in diag. nosis? Would the liability of the physician be affected in any way by the fact that the failure to vise the Roentgen ray was owing to an inability on the part of the patient to meet the expense thereof?

1. The failure to use the Roentgen ray as a means of diagnosis may, under all the facts, be a mere mistake of error or 